\title{
Monitoring checkpoint inhibitors: predictive biomarkers in immunotherapy
}

\author{
Min Zhang, Jingwen Yang, Wenjing Hua, Zhong Li, Zenghui Xu (ه), Qijun Qian (ه) \\ ShangHai Cell Therapy Group Co., Ltd., Shanghai 201805, China \\ (C) The Author(s) 2019. This article is published with open access at link.springer.com and journal.hep.com.cn
}

\begin{abstract}
Immunotherapy has become the fourth cancer therapy after surgery, chemotherapy, and radiotherapy. In particular, immune checkpoint inhibitors are proved to be unprecedentedly in increasing the overall survival rates of patients with refractory cancers, such as advanced melanoma, non-small cell lung cancer, and renal cell carcinoma. However, inhibitor therapies are only effective in a small proportion of patients with problems, such as side effects and high costs. Therefore, doctors urgently need reliable predictive biomarkers for checkpoint inhibitor therapies to choose the optimal therapies. Here, we review the biomarkers that can serve as potential predictors of the outcomes of immune checkpoint inhibitor treatment, including tumor-specific profiles and tumor microenvironment evaluation and other factors.
\end{abstract}

Keywords immune checkpoint; companion diagnosis; PD-L1; tumor mutation burden; immune score

\section{Introduction}

The use of immune checkpoint inhibitors has been one of the hottest frontiers of cancer therapies in recent years. Since the approval of the first therapeutic monoclonal antibody targeting immune checkpoint cytotoxic T lymphocyte-associated antigen 4 (CTLA-4) in 2011, six immune checkpoint inhibitors for three targets have been approved for more than 10 applications. Immune checkpoint therapies have developed rapidly owing to their high efficacies and low side effects relative to those of chemoradiotherapy in advanced cancers. Furthermore, several immune checkpoint inhibitor therapies have achieved remarkable results. The objective response rates of immune checkpoint inhibitor medications pembrolizumab and nivolumab in the treatment of melanoma are 40\%-45\% [1-5]. The combination therapy of pembrolizumab and chemotherapy has become the first-line treatment for non-small cell lung cancer (NSCLC) [6]. Single-drug pembrolizumab first-line treatment for local advanced or metastatic NSCLC in key phase III KEYNOTE-042 study has reached the main endpoint [7]. The success of CheckMate-227 extends the application of nivolumab to advanced NSCLC first-line drugs with tumor

Received August 30, 2018; accepted November 16, 2018

Correspondence: Zenghui Xu, zenghuixu@163.com;

Qijun Qian, qianqj@163.com mutation burden (TMB) greater than $10 \mathrm{~m} / \mathrm{Mb}$ [8]. The success of another clinical trial, IMpower150, extends the first approved PD-L1 inhibitor atezolizumab as the firstline medication of advanced NSCLC. Moreover, phase III clinical trials (CheckMate-214) involving 1096 patients showed that the combined treatment of nivolumab and ipilimumab exhibits a much better curative effect in advanced renal cell carcinoma (RCC) than the first-line treatment scheme recommended by the current guideline [9].

Although immune checkpoint inhibitors show promising results in various tumors, only $20 \%-40 \%$ of patients benefitted from the treatment $[10,11]$. The results of an ipilimumab study showed that the objective response rate of ipilimumab is quite low and only $22 \%$ of patients with advanced melanoma survived for more than 3 years after treatment [12]. Furthermore, the combination of checkpoint inhibitors caused severe immune-related side effects, such as dermatitis, enteritis, and hepatitis. In CheckMate$067,55 \%$ of the patients (172 in 313) suffered grades 3 and 4 side effects due to the combined therapy of nivolumab and ipilimumab, whereas nivolumab or ipilimumab caused only $16 \%(51 / 313)$ and $27 \%(85 / 313)$ suffered grades 3 and 4 side effects when the drugs were individually used [4]. As new drugs, immune checkpoint inhibitors show an average annual cost of more than $\$ 100000$, which is doubled in combined treatment.

Therefore, establishing predictive biomarkers that maximizes the efficacy of checkpoint inhibitors is important. 
One or more biomarkers can be used to predict the effectiveness of treatment and aid the decision-making of oncologists. Overall response rate and the risk of side effects are extremely high when nivolumab and ipilimumab are used in combination. Under such circumstance, relevant biomarkers can be used in determining whether a single drug or drug combinations should be used. However, developing emerging immunotherapies is challenging. The easily defined driver mutations are critical for current companion diagnostics development. The response to immunotherapy is not determined by "driver mutations" but by the complex interactions between tumor cells and the immune system [13].

\section{Tumor-specific profiles}

Unlike molecular targeted drugs that possess well-defined targets, biomarkers are difficult to use in immunotherapy because the tumor-immune process involves the complex interactions between tumors and the immune system. Moreover, immune response varies according to the characteristics of tumors. Currently, five of the six immune checkpoint inhibitors target programmed death-1 (PD-1) and its ligand PD-L1, which is highly expressed in numerous tumors. The binding of PD-L1 to PD-1 on T cells renders tumor cells undetected by immune surveillance, thereby facilitating the proliferation and metastasis of tumor cells. Genomic instability is another important potential tumor biomarker and is closely related to tumor heterogeneity and drug resistance. Driver mutations are the main targets for molecular targeted drugs and are broadly involved in carcinogenesis. However, the direct correlation among driver mutations and the response of patients to immune checkpoint monoclonal antibodies are unknown [13]. The overall mutation burden of tumor may influence the effects of immune checkpoint monoclonal antibodies (Fig. 1).

\section{PD-L1 expression level}

PD-1, PD-L1, and PD-L2 (the other ligand of PD-1), the targets of PD-1/PD-L1 inhibitors, are preferred for predicting the efficacies of PD-1/PD-L1 inhibitors. PDL1 expression in tumors shows stronger correlation with antitumor response in patients than PD-1 expression and thus a better predictive marker [14]. No obvious correlation has been found between patients' clinical response and PD-L2 expression, although PD-L2 can be detected within a similar area of PD-L1 expression. In summary, the PDL1 (Fig. 1) has the greatest value for predicting the efficacy of PD-1/PD-L1 therapy among the immune checkpoints $[15,16]$.

Owing to its excellent prediction potential, PD-L1 expression is extensively applied in the clinical field. Until now, FDA has approved five PD-L1 clinical trials for the adjuvant or companion diagnosis of PD-1/PD-L1 inhibitors. The clinical trials of nivolumab showed that PD-L1 expression predicts clinical response in patients with melanoma, NSCLC, platinum-resistant prostate cancer, RCC, or colorectal cancer. PD-L1 expression on tumor surfaces can be detected by immunohistochemistry

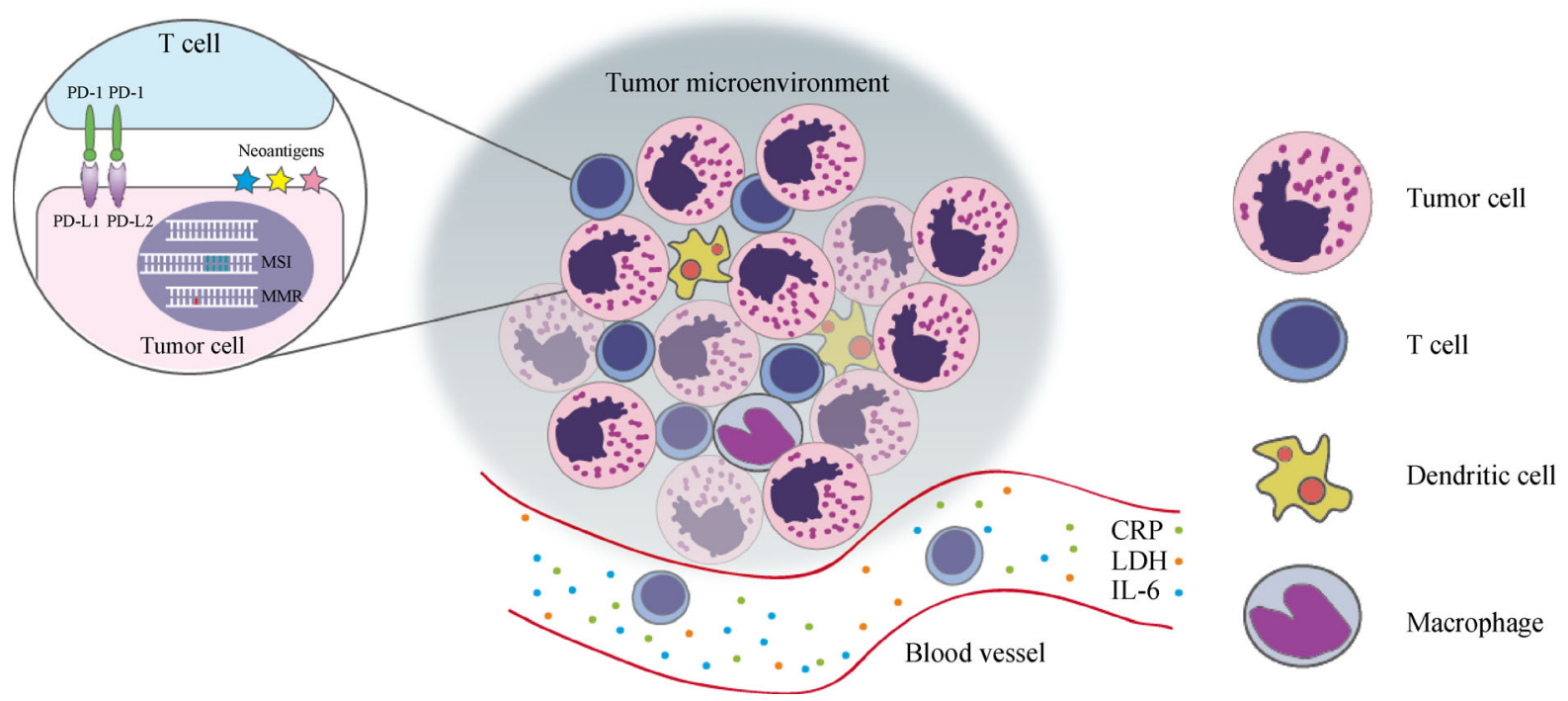

Fig. 1 Potential biomarkers for checkpoint inhibitors in category. Tumor-specific atlas (left) includes the expression of PD-L1, neoantigen, and MSI. Tumor microenvironment (right) includes tumor-infiltrating lymphocytes and immune score (not shown in the figure). Biomarkers in the serum (below) contains molecules CRP, LDH, and IL-6 and lymphocytes in the epithelial serum. 
(IHC) before treatment and compared with the PD-L1 positive cutoff value of $5 \%$. Under this standard, the response rate of $\mathrm{PD}-\mathrm{L} 1$ positive patients is $36 \%(9 / 25)$, and no PD-L1 negative patient responds to treatment $(0 / 17)$ [17]. Basing on these results, FDA approved PD-L1 expression for its use in the adjuvant diagnosis of nivolumab therapy $[1,2,4,18]$. If the clinical trial of nivolumab proves the potential of PD-L1 expression as a predictive biomarker, then the clinical trial of pembrolizumab turns this potential into reality. Three pharmDx tests as companion diagnosis devices have been approved by FDA and can be used for PD-L1 detection in pembrolizumab treatment. In the clinical trial KEYNOTE-001 assessing the likelihood of PD-L1 expression correlation with clinical benefit, the response rate and median overall survival (mOS) of NSCLC patients with PD-L1 expression higher than $50 \%$ increases by $45 \%$ and $11 \%-17 \%$, respectively, relative to those of patients with PD-L1 expression under 50\% [3]. In a different trial KEYNOTE042, NSCLC patients identified with more than 1\% PD-L1 expression have higher response rates and $\mathrm{mOS}$ than those with expression of less than 1\%. FDA also approved two other PD-L1 tests for companion diagnosis and adjuvant diagnosis for atezolizumab and durvalumab [7] (Table 1).

However, the practical use of IHC for detecting the expression level of PD-L1 is still problematic. Although

Table 1 List of diagnostic devices approved by FDA

\begin{tabular}{|c|c|c|c|c|}
\hline Target & $\begin{array}{l}\text { Drug trade name } \\
\text { (generic name) }\end{array}$ & $\begin{array}{l}\text { Device trade } \\
\text { name }\end{array}$ & PMA & Intended use \\
\hline \multirow[t]{6}{*}{$\overline{\text { PD-L1 }}$} & $\begin{array}{l}\text { KEYTRUDE }^{(B)} \\
\text { (Pembrolizumab) }\end{array}$ & $\begin{array}{l}\text { PD-L1 } \\
\text { IHC } 22 \mathrm{C} 3 \\
\text { pharmDx }\end{array}$ & $\mathrm{P} 150013 / \mathrm{S} 011$ & $\begin{array}{l}\text { Companion diagnostic devices } \\
\text { Non-small cell lung cancer (NSCLC) } \\
\text { The specimen should be considered to exhibit PD-L1 expression if TPS } \geqslant 1 \% \\
\text { and high PD-L1 expression if TPS } \geqslant 50 \% \\
\text { Gastric or gastresophageal junction (GEJ) adenocarcinoma } \\
\text { The specimen should be considered to exhibit PD-L1 expression if CPS } \geqslant 1 \\
\text { Cervical cancer } \\
\text { The specimen should be considered to exhibit PD-L1 expression if CPS } \geqslant 1 \\
\text { Urothelial carcinoma } \\
\text { The specimen should be considered to exhibit PD-L1 expression if CPS } \geqslant 10\end{array}$ \\
\hline & & & P150013/S006 & $\begin{array}{l}\text { Companion diagnostic devices } \\
\text { Non-small cell lung cancer (NSCLC) } \\
\text { The specimen should be considered to exhibit PD-L1 expression if TPS } \geqslant 1 \\
\text { and high PD-L1 expression if TPS } \geqslant 50 \%\end{array}$ \\
\hline & & & $\mathrm{P} 150013 / \mathrm{S} 001$ & $\begin{array}{l}\text { Companion diagnostic devices } \\
\text { Non-small cell lung cancer (NSCLC) } \\
\text { The specimen should be considered PD-L1 positive if TPS } \geqslant 50 \% \text { of the } \\
\text { viable tumor cells exhibit membrane staining at any intensity }\end{array}$ \\
\hline & $\begin{array}{l}\text { OPDIVO }^{\circledR} \\
\text { (Nivolumab) }^{\text {Nival }}\end{array}$ & $\begin{array}{l}\text { PD-L1 28-8 } \\
\text { pharmDx }\end{array}$ & $\mathrm{P} 150027 / \mathrm{P} 150027$ & $\begin{array}{l}\text { Complementary diagnostic devices } \\
\text { Non-small cell lung cancer (NSCLC) } \\
\text { A minimum of } 100 \text { viable tumor cells must be present for the specimen to be } \\
\text { considered adequate for PD-L1 evaluation } \\
\text { Melanoma } \\
\text { Specimen is considered PD-L1 positive if } \geqslant 1 \% \text { of melanoma cells exhibit } \\
\text { circumferential and/or partial linear plasma membrane PD-L1 staining of } \\
\text { tumor cells at any intensity }\end{array}$ \\
\hline & $\begin{array}{l}\text { TECENTRIQ }^{\circledR} \\
\text { (Atezolizumab) }\end{array}$ & $\begin{array}{l}\text { PD-L1 } \\
\text { (SP142) }\end{array}$ & $\mathrm{P} 16002 / \mathrm{S} 006$ & $\begin{array}{l}\text { Companion diagnostic devices } \\
\text { Urothelial carcinoma } \\
\text { PD-L1 expression } \geqslant 5 \% \text { IC is indicated as an aid in identifying urothelial } \\
\text { carcinoma patients } \\
\text { Non-small cell lung cancer (NSCLC) } \\
\text { PD-L1 expression } \geqslant 50 \% \text { TC or } \geqslant 10 \% \text { IC may be associated with enhanced } \\
\text { overall survival }\end{array}$ \\
\hline & $\begin{array}{l}\text { IMFINZI }^{\circledR} \\
\text { (Durvalumab) }\end{array}$ & PD-L1 SP263 & P160046 & $\begin{array}{l}\text { Complementary diagnostic devices } \\
\text { Advanced or metastatic urothelial carcinoma } \\
\text { PD-L1 status is considered high if any of the following are met: }(1) \geqslant 25 \% \text { of } \\
\text { tumor cells exhibit membrane staining; (2) ICP }>1 \% \text { and IC }+\geqslant 25 \% ;(3) \text { ICP } \\
\quad=1 \% \text { and IC }+=100 \%\end{array}$ \\
\hline
\end{tabular}

TPS: tumor proportion score, percentage of viable tumor cells showing partial or complete membrane staining at any intensity; CPS: combined positive score, the number of PD-L1 staining cells (tumor cells, lymphocytes, macrophages); ICP: immune cells present, the percent of tumor area occupied by any tumorassociated immune cells; IC + : the percentage of tumor-associated immune cells with staining $(\mathrm{IC}+)$ at any intensity above background; PMA: premarket approval. The data were obtained from the official website of FDA (https://www.fda.gov/MedicalDevices/ProductsandMedicalProcedures/InVitroDiagnostics/ ucm301431.htm). 
the increase of response rate in PD-1/PD-L1 inhibitor treatments correlate with the upregulation of PD-L1 expression, some patients with negative PD-L1 expression respond to these treatments, and thus PD-L1 expression is the only effective biomarker for PD-1/PD-L1 inhibitor efficacy. For example, although patients with positive PDL1 expression show great potential to improved response and survival, several independent studies have shown that a small portion of patients with negative PD-L1 expression can also benefit from nivolumab therapy, and this result causes a clinical and ethical false negative by IHC testing that excludes patients who may also benefit from the therapy. In summary, both biological and technical complexities hamper the maturation of PD-L1 expression as a universal predictive biomarker for immunotherapy [19].

Underlying the false negatives, several objective factors influence the accuracy of PD-L1 expression as a single perfect biomarker for checkpoint inhibitors. First, PD-L1 expression in a single tumor sample of a cancer patient can be affected by numerous factors. Therefore, determining the clinical benefit of immunotherapy by only evaluating the expression of PD-L1 in a single tumor sample is insufficient. Among immune mechanisms, PD-L1 expression is a secondary product that can be induced by proinflammatory cytokines and is thus dynamic [14]. This finding raises a question of whether a single tumor sample collected during initial diagnosis can reflect a patient's current state, particularly after multiple antitumor treatments. PD-L1 expression is regional and is mainly expressed in areas where tumor cells and lymphocytes accumulate. Therefore, owing to the limitations of sampling, considering the possibility of false negatives is necessary [20]. In the sample evaluation of immunotherapy patients with RCC, PD-L1 expression inconsistency between the two different sampling areas is found in $20.8 \%$ of patients. This result indicates that tumor immune heterogeneity also affects the evaluation of the accuracy of overall PD-L1 expression [19]. Therefore, using PD-L1 as a single predictor is unlikely. Many research groups attempted an automatic analysis of multi-IHC result to predict the response of patients to immune checkpoint inhibitors [21,22].

In addition to these objective factors, technical factors affect the determination of PD-L1 expression by IHC. Different pharmaceutical companies use different companion diagnostic techniques to determine the efficacy of PD1 inhibitors. Correspondingly, IHC methods used to detect PD-L1 expression are diverse [23]. Different studies use different cutoff values to define PD-L1 positivity. Without a universal standard, collecting a large amount of data for the assessment of the pros and cons of using PD-L1 as a companion diagnostic predictive marker or cross-comparing the patient's prognosis is difficult $[24,25]$. Furthermore, PD-L1 is expressed not only in tumor cells but also in other components of the tumor microenvironment, such as macrophages and lymphocytes.

Researchers have exerted considerable effort to overcome these technical problems and have already achieved some accomplishments. Not long after the advent of companion diagnostics, pharmaceutical companies and companion diagnostic companies have reached a consensus on the use of PD-L1 expression as a predictive marker for anti-PD-1/PD-L1 therapy and developed a preliminary protocol. The purpose of this protocol is to conduct cross-industrial cooperation, analyze and compare information generated by different diagnostic results, and promote the establishment of post-marketing standards and practical guidelines. In the past two years, 81 patients with NSCLC treated with pembrolizumab or nivolumab have been tested by using Ventana SP263, Dako 28-8, and Merck 22C3. Further study showed that different detection methods have good consistency (96\%) [26]. Although this result was exciting, the results of the additional tests performed in other different tumors must be further verified.

\section{Mutation burden, neoantigen burden, and genome instability}

In addition to the expression of PD-L1 on the tumor surface mentioned above, several other tumor characteristics relating to immune process, such as tumor mutation burden (TMB) (Fig. 1), also show great potential for development into predictive biomarkers. The response of immune checkpoint inhibitors are not significantly correlated with driver mutations [13], but the overall mutation burden may affect the response of immune checkpoint inhibitors [27,28]. Tumor mutation-related database searching shows that different tumor types undergo different somatic mutations. The approved indications of PD-1 and PD-L1 inhibitors for melanoma, lung cancer, and bladder cancer show the highest median burden of mutations [29].

The clinical response of checkpoint inhibitors is related to the total mutation burden of tumor cells. One study analyzed the correlation between mutational burden and clinical outcomes by sequencing the whole exons of patients with advanced melanoma treated with ipilimumab. Patients with numerous mutations and nonsynonymous mutations show long overall survival (OS) rates [30]. Similarly, two groups of retrospective studies of pembrolizumab analyzed the mutation burden of patients with advanced NSCLC and found that patients with high nonsynonymous mutation burden show long median progression-free survival. In other words, patients with high mutational burden show a long sustained clinical benefit ( $>6$ months) [28]. The Phase II clinical trial of atezolizumab in the treatment of advanced bladder cancer patients shows that the median mutation burden is 
significantly higher in patients who responded to treatment than in patients who did not. The response rate is not associated with tumor genome expression subtypes and immune cell subtypes [31]. In CheckMate-227 led by Memorial Sloan Kettering Cancer Center, advanced lung cancer patients with high TMB (more than $10 \mathrm{~m} / \mathrm{Mb}$ ) and who accepted an Opdivo + Yervoy antibody combinational immunotherapy exhibit a better PFS and ORR than patients who received pemetrexed [8]. However, some patients with high mutation burdens do not respond to immune checkpoint inhibitors, although some with low mutation burdens still respond.

This result poses a question about how to link mutation burden to patients' response to immunotherapy. Immune response is believed to be primarily induced by newly produced antigens rather than by high non-synonymous mutation burden because of the mutation burden. T cells that do not react to existing antigens can react to antigens generated owing to the increased mutation rate of tumor cells. Most of these mutations are "passenger mutations," which can affect the immune editing process and exert selective pressure on the immune system [19,32]. Rizvi and colleagues found that in patients responding well to pembrolizumab, the reactivation of neoantigen-specific $T$ cells is correspondingly increased, indicating that the specific neoantigen is the main driving force of response to immunotherapy. They also found that response to pembrolizumab is associated with the biomarkers of tobacco carcinogen-related mutations and patients with high smoking labels show a great likelihood of responding to PD-1 therapy [28]. Immune checkpoint inhibitors exhibit therapeutic effects on other smoking-related malignancies, such as esophageal cancer, head and neck squamous cell carcinoma, and bladder cancer. In addition to the overall mutation burden and the neoantigen burden, low heterogeneity of neoantigen within a tumor is a noticeable factor.

McGranahan et al. found that NSCLC patients with high mutational burdens and low tumor heterogeneity received continuous benefit from pembrolizumab treatment [33]. The quality of neoantigen rather than its quantity seems to be crucial to the initiation of immune checkpoint inhibitortriggered immune response. Activated antigens or neoantigens are functionally homologous to microbial or viral antigenic peptides [30,34]. Birnbaum et al. found that $\mathrm{T}$ cell receptors (TCRs) that recognize antigen peptides presented by the class I and class II of major histocompatibility complex I and II can cross-react with thousands of related peptides. The core sequence of these peptides is normally 45 amino acids. The peptide segments among these peptides are extremely similar to some of the genomic fragments in the microorganisms in the environment [34]. Snyder et al. discovered novel potential antigenic peptides with tetrapeptide cores in patients who responded to CTLA-4 mAb therapy [30]. However, Van
Allen et al. did not find a common core tetrapeptide in their trial [35]. A vaccine or specific RNA for a new antigen can be designed to treat tumors with good clinical effect. This work establishes the presence of neoantigens from the side.

Interestingly, mutations of tumor cells, especially mutations involved in DNA replication and mismatch repair, are associated with the effects of tumor immunotherapy. The high-fidelity replication of DNA was performed by the DNA polymerase and the respective exonuclease proofreading domain encoded by POLE and POLD. The mismatch repair (MMR) protein also plays a vital role in ensuring DNA integrity. The probability of an intact DNA polymerase in making a replication error is $10^{-5}$ to $10^{-4}$; however, after the effect of MMR proteins, the probability of error is reduced to $10^{-10}$ [36-38].

The presence of MSI, which indicates mutations in the MMR protein, correlates strongly with the clinical benefit of treatment with immune checkpoint inhibitors (Fig. 1). The junction of these mutant phenotypes with the immunotherapeutic responses can be explained by the production of neoantigens. Le and colleagues showed that MMR-inactivated patients with colorectal cancer and other cancers show an improved clinical response to pembrolizumab therapy [27]. Similarly, NSCLC patients with mutations in the POLE and POLD genes also exhibit objective clinical response to pembrolizumab therapy. Therefore, the clinician can determine whether the patient can benefit from immunotherapy based on the patient's DNA mismatch repair ability [28]. In May 2017, FDA approved the use of pembrolizumab by Merck in the treatment of all MSI-H/dMMR solid tumors. Le et al. evaluated the effect of using PD-1 inhibitors in 12 different types of cancers with severe MMR deficiency. Approximately $53 \%$ of the patients show an objective imaging response, $21 \%$ show a complete response and a longlasting response, and the median progression-free survival is prolonged [39].

\section{Transcriptome tag}

Nongenomic tags may also serve as predictive biomarkers for predicting immunotherapeutic response. Studies of transcriptome tags have been carried out from a PD-1 monoclonal antibody test treating melanoma patients, in which the unique innate label of the anti-PD-1 mAbrelated marker (innate PD-1 resistance to the monoclonal antibody, IPRES) was discovered. Twenty-six other transcriptome tags (IPRES as well) were revealed by RNA sequencing and gene cluster analysis of tumor samples of 28 melanoma patients treated with PD-1 inhibitors. By those studies, patients with rich IPRES usually show short survival rates. Similar transcriptome subtypes can also be found in other tumors type from the Tumor Genome Database, suggesting that IPRES may also be useful on other occasions $[19,40]$. 


\section{Tumor microenvironment}

The antitumor immune process mentioned above is essentially the interaction between tumor and immune system and not only relates to the characteristics of the tumor itself but also to components in the tumor microenvironment. These components include immune cells and associated molecules that can assist or hinder immune response [19]. According to the patterns of T cells or inflammatory $\mathrm{T}$ cell infiltration, the tumor microenvironments can be classified into two types. The first type is enriched with $\mathrm{T}$ cells or inflammatory cells and is often accompanied by the upregulated expression of $\mathrm{T}$ cell activating factors, type I interferon, and Th1-related cytokines and chemokines, which may in reverse contribute to the recruitment and function of $T$ cells. In the second type, the proportion of inflammatory $\mathrm{T}$ cells is lower than any of the other types of immune cells or components, such as tumor-associated macrophages (TAMs), myeloid-derived suppressor cells (MDSCs), and some immunosuppressive factors (Th2-related cytokines and chemokines) are found. Cells in these two kinds of microenvironments are involved in different immune processes. Immune activation cells include $\mathrm{CD} 8^{+}$cytotoxic $\mathrm{T}$ cells, $\mathrm{CD} 4^{+} \mathrm{Th} 1$ cells, $\mathrm{NK}$ cells, and mature dendritic cells. Immune suppression cells include TAMs and MDSCs. Some soluble molecules and membrane proteins are associated with certain tumor microenvironment as well [41]. In the following part, we will discuss these components as potential markers in tumor microenvironments associated with companion diagnostic targets (Fig. 1).

\section{Tumor-infiltrating lymphocytes (TILs)}

Among the factors in tumor microenvironment, TILs (Fig. 1) may be of the greatest value for the prediction of prognosis and response to therapy of many solid tumors and cancers, such as colorectal cancer, stem cell carcinoma, gallbladder cancer, esophageal cancer, ovarian cancer, endothelial cell carcinoma, cervical cancer, bladder cancer, NSCLC, prostate cancer, head-and-neck cancer, and breast cancer [42-45]. Patients with tumors infiltrated by TILs are more susceptible to immunotherapies [41]. Studies by Galon showed that CD3- and CD8-positive colorectal cancer patients exhibit significantly high OS rates [42]. Patients with CD8-positive melanomas show high PD-L1 expression, improved prognosis, and delayed brain metastasis [46]. Meanwhile, patients with CD3positive ovarian cancer exhibit high PFS and OS rates [47]. Moreover, T cell-activating factors expressed by TILs in tumor tissues, such as CD25 and CD134 (OX40), correlate with long survival rates in patients with metastatic melanoma [48]. The infiltration levels of CD4 and CD8 positive T cells are prognostic indicators in NSCLC [49], whereas other immune activation markers are still under study, such as inducible T cell co-stimulator (ICOS), which belongs to CD28/CTLA-4 family and is expressed after activation of T cells. ICOS is believed to play an important role in the proliferation of $\mathrm{T}$ cells and production of memory $\mathrm{T}$ cells. In the new adjunctive therapy trial of ipilimumab treating bladder cancer, the number of high ICOS and CD4-positive $\mathrm{T}$ cells increased inside and around the tumors among 12 patients, which may be associated with the clinical response of ipilimumab therapy. A similar phenomenon is also observed in trials of ipilimumab or pembrolizumab treating prostate cancer, breast cancer, and mesothelioma [50-53] or pembrolizumab treating melanoma [54]. These $\mathrm{ICOS}^{+} \mathrm{CD}^{+}{ }^{+} \mathrm{T}$ cells data can be used to monitor the bioactivity of CTLA-4 antibodies [32].

The survival extension in patients with colorectal cancer, melanoma, or NSCLC is related to the infiltration of lymphocytes in tumor biopsy samples [55-57]. The structural heterotopia of lymph node in colorectal cancer and melanoma indicates good survival in cancer patients [58]. In the biopsy samples of stage III NSCLC patients, PFS and OS of patients with high lymphocyte density and $\mathrm{CD}^{+}$TILs are longer than those with low densities [59]. Inflammatory $\mathrm{T}$ cells in tumor microenvironment are related to improved clinical benefit of melanoma-associated antigen 3 vaccine and high dose interleukin-2 (IL-2) immunotherapy [41]. Therefore, the base status of TILs may also be used to predict the efficacy of immune checkpoint inhibitors [60].

Apart from the interesting and meaningful findings mentioned above, $\mathrm{CD} 8^{+} \mathrm{T}$ cells exist in patients regardless of whether they respond or not to immunotherapy, indicating that efforts are still needed before TILs can be developed into an independent biomarker for predicting the clinical effect of immunotherapy. In stage II clinical trial of ipilimumab for the treatment of metastatic melanoma patients, TIL status is not directly associated with improved clinical outcome (complete or partial response and PFS). However, after two courses ipilimumab treatment, the bioactivity of TILs in tumor biopsy samples is related to improved clinical indexes [61]. In the later KEYNOTE-001 trial by Tumeh and his colleagues, TILs correlate with the response to pembrolizumab treatment in patients with melanoma. By quantification of TILs in and around tumor tissue, $\mathrm{CD} 8^{+} \mathrm{T}$ cells instead of $\mathrm{CD}^{+} \mathrm{T}$ cells of tumor samples from patients responding to therapy, whether in or around tumor tissues, are more than those from non-responding patients [25]. Similar with the ipilimumab trials treating metastatic melanoma, in the test of pembrolizumab, $\mathrm{CD}^{+} \mathrm{T}$ cell level continuously increases in responding patients, whereas no change was found in non-responding ones [51]. In another research of 
pembrolizumab treating melanoma, compared to nonresponding patients, the base densities of $\mathrm{CD}^{+}$and $\mathrm{CD}^{+}$ $\mathrm{T}$ cells in responding patients are moderately related to $\mathrm{CD}^{2} 5 \mathrm{RO}^{+} \mathrm{T}$ cell, whereas after PD-1 treatment, these two factors are significantly correlated. However, given the existence of $\mathrm{CD}^{+} \mathrm{T}$ cells in both responding and nonresponding patients, the number of TILs is less likely to be an independent biomarker in predicting the clinical effect of immunotherapy [60].

\section{Immune score}

Immune cells distribute both in and around tumor tissue. A score matrix evaluating the distribution of TILs in both sites can be a good tool for tumor classification and therapy response prediction, increasing the accuracy of OS prediction of early-stage colorectal cancer and providing evidence for theoretical studies on the infiltration of immune cells in the interior and edges of the tumor $[42,62]$.

This evaluation is called the immune score, which levels the concentration of the two lymphocytes cytotoxic T cells $\left(\mathrm{CD}^{+}\right)$and memory $\mathrm{T}$ cells $\left(\mathrm{CD} 45 \mathrm{RO}^{+}\right)$inside tumor and surrounding the infiltration region. This evaluation system scores from 0 to 4 , represented by I0 to I4, which refer to a low and high concentration of both lymphocytes in both sites, respectively $[62,63]$. The immune score had already been applied in prognosis in colorectal cancer $[64,65]$. According to the tumor TNM classification system by American Joint Committee on Cancer (AJCC), an international union of cancer, the immune score was used by Mlecnik and his colleagues in an evaluation on the relationship between scores and procession of primary tumor and recurrence rate of 599 stage I colorectal tumor patients. The immune score is strongly correlated with disease-free survival, disease-specific survival, and overall survival, and patients with coordinated $\mathrm{T}$ cell responses usually show improved prognosis. Multivariate analysis also verifies that the immune score system is better than the TNM classification system of AJCC in predicting the recurrence and survival of patients with colorectal cancer [65]. In a study by Pagès et al., the immune score system is used as an independent predictor for tumor recurrence and survival in early-stage colorectal cancer patients, confirming that the score is directly related to the levels of immune response in tumor sites and prognosis [44]. The prediction effects of the immune score in various international clinical trials are quite promising [66].

The immune score may become a potential marker of patients' response to immune checkpoint inhibitors by considering the relationship between the presence of $\mathrm{CD} 8^{+}$ $\mathrm{T}$ cells at the margin of tumor infiltration and the expression of PD-1 and PD-L1 in tumor and tumor microenvironment $[25,62,67]$. The application of the immune score in predicting melanoma is being studied.
However, the evaluation standard of immune score is still a challenge because of the complexity of immune response in melanoma. To date, the immune score assessment of melanoma has been applied in evaluating metastatic lymph node tissue samples, which are the most easily available malignant tissues in patients. The immune score can be helpful for treatment planning and is especially beneficial for stage III patients after tumor resection and lymph node dissection. However, the effectiveness of lymphedemaonly evaluation methods is still questionable because lymph nodes are rich in CD3 and CD20 positive lymphocytes and exhibit different patterns of immune infiltration compared with other metastatic lesions. Further studies are ongoing assessing the relationship between different immune patterns and the response and benefit of patients with malignant melanoma to immunological checkpoint suppressive therapy $[64,67]$.

The immune score is also one of the candidate biomarkers in NSCLC. Analysis of tumor slides from 536 stage I NSCLC patients shows that high positive expression of PD-1 in lymphocytes and intraepithelial TILs is associated with high disease-specific survival (HR $=1.81 ; 95 \%$ CI $1.37-2.40 ; P<0.001)$. Multivariate analysis shows that these two factors contribute significantly, indicating that they are independent prognostic factors [68].

Although the knowledge of immunological scoring gained from current studies is exciting, technical barriers still need to be overcome to apply this promising technique to conventional clinicopathological and oncology practices. Strong software solutions are required to automate the analysis of TILs, speed up processing and turnover, and accurately and effectively quantify the density of large numbers of immune cells $[62,64]$. The importance of developing and maintaining international consensus on immunological scoring definitions and methodological strategies will increase as the concept of immune scoring continues to be applied to all aspects of the clinic [66].

\section{Multi-factor evaluation}

Multiple factor evaluation system is used to assess the results in multiple clinical trials. For example, multispectral IHC method is used to analyze the expression of CD3, CD8, forkhead box P3 (FoxP3), CD163, and PD-L1 in melanoma tissue sections to predict whether patients receiving adoptive cell therapy can successfully produce TILs. CD8 ${ }^{+} \mathrm{T}$ cells alone are not sufficient to predict the existence of TILs, but the successful growth of TILs is closely related to the proportion of $\mathrm{T}$ cells regulated by $\mathrm{CD}^{+} \mathrm{T}$ cells and $\mathrm{CD}^{+} \mathrm{FoxP}^{+}(P=0.006$, positive predictive $=91 \%$, negative predictive $=86 \%$ ) [21]. Tumeh and his colleagues used this multi-factor evaluation in the KEYNOTE-001 test of pembrolizumab therapy [25]. 


\section{Other markers}

\section{Biomarkers in the serum}

Biomarkers in serum are easily accessed and noninvasive to patients, which make them potential diagnostic markers with great clinical values in the future. Currently published studies have reviewed peripheral blood biomarkers in immunotherapy [19]. Potential biomarkers in the blood can be soluble molecules, such as serum protein and circulating tumor DNA, or cells, such as tumor cells, T cell subsets, or other immune cell subsets. The study of soluble molecules in serum as biomarkers dates back to the late 1990s. The potential effects of soluble proteins in serum of patients was first recognized in the study of high-dose IL-2 in the treatment of melanoma and RCC. The main results of immune checkpoint inhibitors are derived from the study of ipilimumab. The upregulation of vascular endothelial growth factor and C-reactive protein (Fig. 1) is observed in patients from the clinical trials of both ipilimumab and IL2 therapies [69]. Serum lactate dehydrogenase (LDH) (Fig. 1) levels are negatively correlated with clinical responses of patients [70,71].

Similar to serum soluble molecules, peripheral blood cells, such as T cells, NK cells, dendritic cells, macrophages, and tumor cells, are also potential predictors (Fig. 1). Among these factors, lymphocytes are the most commonly studied. In a study on ipilimumab, reduction of regulatory $\mathrm{CD}^{+} \mathrm{FoxP}^{+} \mathrm{T}$ cell and the increase of the absolute number of lymphocytes during treatment are significantly associated with disease control rates and survival rates [72]. In other similar trials, the increase of absolute lymphocyte counts (ALCs) and the improvement of clinical benefit are simultaneous. However, from some other studies, ALCs always increase whether or not the patients benefitted clinically [73]. In the study on 209 patients by Martens et al., multiple changes are related with improved prognosis, including low LDH and high number of lymphocytes, monocytes, eosinophils, and regulatory $\mathrm{T}$ cells, suggesting that the evaluation of multiple dynamic cell groups may be a good predictor [74]. Studies also involve neutrophils, MDSCs, and autoantibodies. In general, rather than predictive, these markers may exhibit strong indicating effect on prognosis [73,75-77]. In general, although these indicators can be commercially useful, some problems are still unsettled, concerning clinical algorithms for treatment decisions and accompanying diagnostic testing.

\section{Microbiome}

In recent years, an increasing number of studies have pointed out the connection between the gut microbiome and efficiencies of checkpoint inhibitor immunotherapies. The human body is a symbiont of a human being and various microbes. The effect of microbes on human growth is a comprehensive metabolic process. Microbes can change human antitumor immunity in various ways. Individual microorganism groups may affect patient response to immune checkpoint inhibitors, making human microbiome a potential biomarker for such therapy [78]. In 2015, two articles in Science showed that some microbes can improve the response of mice to CTLA-4 monoclonal antibodies $[79,80]$. In early 2018 , two papers from Science reported the similar fact $[81,82]$. Certain microbes, such as Bifidobacterium longum, Collinsella Aerofaciens, and Enterococcus faecium, are also found to increase the response of melanoma patients to PD-1 antibodies [83]. The correlation between microbial groups and the effect of immunological checkpoint inhibitors still require confirmation [78].

\section{Summary}

With the study of predictive markers for checkpoint inhibitors therapy getting increasingly comprehensive, many reviews or related articles are systematically classified and sorted these competitive or potential predictive biomarkers or summarized the clinical application of each of them. Recently, the development of immune checkpoint inhibitor biomarkers has benefitted from the achievements of some large-scale prospective clinical trials. The most widely studied immune checkpoint inhibitor biomarker is the PD-L1 expression in the tumor-specific profile. Although, a series of blockades of PD-L1 expression to overcome still exists, four companion diagnostic tests and two auxiliary diagnostic tests have already been approved by the FDA. TMB and microsatellite instability are also most likely to be adopted as predictive biomarkers. On the other hand, the evaluation of tumor microenvironment can be very useful theoretically considering it being a direct reflection of interaction of tumor and immune cells in immunotherapy, although it is still not being used in the clinic. The use of biomarkers in the peripheral blood and microbiome as an actual predictive biomarker for checkpoint-based therapy is still distant.

\section{Acknowledgements}

This work was supported by Shanghai Special Fund for Informatization Development (No. 201602037) and Development Initiating Grand of Shanghai Service Community.

\section{Compliance with ethics guidelines}

Min Zhang, Jingwen Yang, Wenjing Hua, Zhong Li, Zenghui Xu, and Qijun Qian declare that they have no financial conflicts of interest. This manuscript is a review article and does not involve a 
research protocol requiring approval by a relevant institutional review board or ethics committee.

Open Access This article is distributed under the terms of the Creative Commons Attribution 4.0 International License (http:// creativecommons.org/licenses/by/4.0/), which permits unrestricted use, distribution, and reproduction in any medium, provided the appropriate credit is given to the original author(s) and the source, and a link is provided to the Creative Commons license, indicating if changes were made.

\section{References}

1. Borghaei H, Paz-Ares L, Horn L, Spigel DR, Steins M, Ready NE, Chow LQ, Vokes EE, Felip E, Holgado E, Barlesi F, Kohlhäufl M, Arrieta O, Burgio MA, Fayette J, Lena H, Poddubskaya E, Gerber DE, Gettinger SN, Rudin CM, Rizvi N, Crinò L, Blumenschein GR Jr, Antonia SJ, Dorange C, Harbison CT, Graf Finckenstein F, Brahmer JR. Nivolumab versus docetaxel in advanced nonsquamous non-small-cell lung cancer. N Engl J Med 2015; 373(17): $1627-1639$

2. Brahmer J, Reckamp KL, Baas $\mathrm{P}$, Crinò L, Eberhardt WE, Poddubskaya E, Antonia S, Pluzanski A, Vokes EE, Holgado E, Waterhouse D, Ready N, Gainor J, Arén Frontera O, Havel L, Steins M, Garassino MC, Aerts JG, Domine M, Paz-Ares L, Reck M, Baudelet C, Harbison CT, Lestini B, Spigel DR. Nivolumab versus docetaxel in advanced squamous-cell non-small-cell lung cancer. N Engl J Med 2015; 373(2): 123-135

3. Garon EB, Rizvi NA, Hui R, Leighl N, Balmanoukian AS, Eder JP, Patnaik A, Aggarwal C, Gubens M, Horn L, Carcereny E, Ahn MJ, Felip E, Lee JS, Hellmann MD, Hamid O, Goldman JW, Soria JC, Dolled-Filhart M, Rutledge RZ, Zhang J, Lunceford JK, Rangwala R, Lubiniecki GM, Roach C, Emancipator K, Gandhi L; KEYNOTE-001 Investigators. Pembrolizumab for the treatment of nonsmall-cell lung cancer. N Engl J Med 2015; 372(21): 2018-2028

4. Larkin J, Chiarion-Sileni V, Gonzalez R, Grob JJ, Cowey CL, Lao CD, Schadendorf D, Dummer R, Smylie M, Rutkowski P, Ferrucci PF, Hill A, Wagstaff J, Carlino MS, Haanen JB, Maio M, MarquezRodas I, McArthur GA, Ascierto PA, Long GV, Callahan MK, Postow MA, Grossmann K, Sznol M, Dreno B, Bastholt L, Yang A, Rollin LM, Horak C, Hodi FS, Wolchok JD. Combined nivolumab and ipilimumab or monotherapy in untreated melanoma. N Engl J Med 2015; 373(1): 23-34

5. Robert C, Long GV, Brady B, Dutriaux C, Maio M, Mortier L, Hassel JC, Rutkowski P, McNeil C, Kalinka-Warzocha E, Savage KJ, Hernberg MM, Lebbé C, Charles J, Mihalcioiu C, ChiarionSileni V, Mauch C, Cognetti F, Arance A, Schmidt H, Schadendorf D, Gogas H, Lundgren-Eriksson L, Horak C, Sharkey B, Waxman IM, Atkinson V, Ascierto PA. Nivolumab in previously untreated melanoma without BRAF mutation. N Engl J Med 2015; 372(4): 320-330

6. Reck M. Pembrolizumab as first-line therapy for metastatic nonsmall-cell lung cancer. Immunotherapy 2018; 10(2): 93-105

7. Tony Mok YLW, Watson PA, Zhang J, Rangwala RA, Lopes G. Phase 3 KEYNOTE-042 trial of pembrolizumab (MK-3475) versus platinum doublet chemotherapy in treatment-naive patients (pts) with PD-L1-positive advanced non-small cell lung cancer (NSCLC). J Clin Oncol. 2015; 33(15_suppl): TPS8105

8. Hellmann MD, Ciuleanu TE, Pluzanski A, Lee JS, Otterson GA, Audigier-Valette C, Minenza E, Linardou H, Burgers S, Salman P, Borghaei H, Ramalingam SS, Brahmer J, Reck M, O’Byrne KJ, Geese WJ, Green G, Chang H, Szustakowski J, Bhagavatheeswaran P, Healey D, Fu Y, Nathan F, Paz-Ares L. Nivolumab plus ipilimumab in lung cancer with a high tumor mutational burden. $\mathrm{N}$ Engl J Med 2018; 378(22): 2093-2104

9. Motzer RJ, Tannir NM, McDermott DF, Arén Frontera O, Melichar B, Choueiri TK, Plimack ER, Barthélémy P, Porta C, George S, Powles T, Donskov F, Neiman V, Kollmannsberger CK, Salman P, Gurney H, Hawkins R, Ravaud A, Grimm MO, Bracarda S, Barrios CH, Tomita Y, Castellano D, Rini BI, Chen AC, Mekan S, McHenry MB, Wind-Rotolo M, Doan J, Sharma P, Hammers HJ, Escudier B; CheckMate 214 Investigators. Nivolumab plus ipilimumab versus sunitinib in advanced renal-cell carcinoma. N Engl J Med 2018; 378 (14): 1277-1290

10. Márquez-Rodas I, Cerezuela $\mathrm{P}$, Soria A, Berrocal A, Riso A, González-Cao M, Martín-Algarra S. Immune checkpoint inhibitors: therapeutic advances in melanoma. Ann Transl Med 2015; 3(18): 267

11. Lovell RA, Schaeffer DJ, Hooser SB, Haschek WM, Dahlem AM, Carmichael WW, Beasley VR. Toxicity of intraperitoneal doses of microcystin-LR in two strains of male mice. J Environ Pathol Toxicol Oncol 1989; 9(3): 221-237

12. Schadendorf D, Hodi FS, Robert C, Weber JS, Margolin K, Hamid O, Patt D, Chen TT, Berman DM, Wolchok JD. Pooled analysis of long-term survival data from phase II and phase III trials of ipilimumab in unresectable or metastatic melanoma. J Clin Oncol 2015; 33(17): 1889-1894

13. Weber JS, D’Angelo SP, Minor D, Hodi FS, Gutzmer R, Neyns B, Hoeller C, Khushalani NI, Miller WH Jr, Lao CD, Linette GP, Thomas L, Lorigan P, Grossmann KF, Hassel JC, Maio M, Sznol M, Ascierto PA, Mohr P, Chmielowski B, Bryce A, Svane IM, Grob JJ, Krackhardt AM, Horak C, Lambert A, Yang AS, Larkin J. Nivolumab versus chemotherapy in patients with advanced melanoma who progressed after anti-CTLA-4 treatment (CheckMate 037): a randomised, controlled, open-label, phase 3 trial. Lancet Oncol 2015; 16(4): 375-384

14. Taube JM, Young GD, McMiller TL, McMiller TL, Chen SM, Salas JT, Pritchard TS, Xu HY, Meeker AK, Fan JH, Cheadle C, Berger AE, Pardoll DM, Topalian SL. Differential expression of immuneregulatory genes associated with PD-L1 display in melanoma: implications for PD-1 pathway blockade. Clin Cancer Res 2015; 21 (17): 3969-3976

15. Herbst RS, Soria JC, Kowanetz M, Fine GD, Hamid O, Gordon MS, Sosman JA, McDermott DF, Powderly JD, Gettinger SN, Kohrt HE, Horn L, Lawrence DP, Rost S, Leabman M, Xiao Y, Mokatrin A, Koeppen H, Hegde PS, Mellman I, Chen DS, Hodi FS. Predictive correlates of response to the anti-PD-L1 antibody MPDL3280A in cancer patients. Nature 2014; 515(7528): 563-567

16. Taube JM, Klein A, Brahmer JR, Xu HY, Pan XY, Kim JH, Chen LP, Pardoll DM, Topalian SL, Anders RA. Association of PD-1, PD1 ligands, and other features of the tumor immune microenvironment with response to anti-PD-1 therapy. Clin Cancer Res 2014; 20 (19): 5064-5074

17. Topalian SL, Hodi FS, Brahmer JR, Gettinger SN, Smith DC, 
McDermott DF, Powderly JD, Carvajal RD, Sosman JA, Atkins MB, Leming PD, Spigel DR, Antonia SJ, Horn L, Drake CG, Pardoll DM, Chen L, Sharfman WH, Anders RA, Taube JM, McMiller TL, Xu H, Korman AJ, Jure-Kunkel M, Agrawal S, McDonald D, Kollia GD, Gupta A, Wigginton JM, Sznol M. Safety, activity, and immune correlates of anti-PD-1 antibody in cancer. N Engl J Med 2012; 366(26): 2443-2454

18. Motzer RJ, Escudier B, McDermott DF, George S, Hammers HJ, Srinivas S, Tykodi SS, Sosman JA, Procopio G, Plimack ER, Castellano D, Choueiri TK, Gurney H, Donskov F, Bono P, Wagstaff J, Gauler TC, Ueda T, Tomita Y, Schutz FA, Kollmannsberger C, Larkin J, Ravaud A, Simon JS, Xu LA, Waxman IM, Sharma P; CheckMate 025 Investigators. Nivolumab versus everolimus in advanced renal-cell carcinoma. N Engl J Med 2015; 373 (19): 1803-1813

19. Lim JS, Sundar R, Chénard-Poirier M, Lopez J, Yap TA. Emerging biomarkers for PD-1 pathway cancer therapy. Biomarkers Med 2017; 11(1): 53-67

20. Taube JM, Anders RA, Young GD, Xu H, Sharma R, McMiller TL, Chen S, Klein AP, Pardoll DM, Topalian SL, Chen L. Colocalization of inflammatory response with B7-h1 expression in human melanocytic lesions supports an adaptive resistance mechanism of immune escape. Sci Transl Med 2012; 4(127): 127ra37

21. Feng Z, Puri S, Moudgil T, Wood W, Hoyt CC, Wang C, Urba WJ, Curti BD, Bifulco CB, Fox BA. Multispectral imaging of formalinfixed tissue predicts ability to generate tumor-infiltrating lymphocytes from melanoma. J Immunother Cancer 2015; 3(1): 47

22. Stack EC, Foukas PG, Lee PP. Multiplexed tissue biomarker imaging. J Immunother Cancer 2016; 4(1): 9

23. Patel SP, Kurzrock R. PD-L1 expression as a predictive biomarker in cancer immunotherapy. Mol Cancer Ther 2015; 14(4): 847-856

24. Sun WY, Lee YK, Koo JS. Expression of PD-L1 in triple-negative breast cancer based on different immunohistochemical antibodies. J Transl Med 2016; 14(1): 173

25. Tumeh PC, Harview CL, Yearley JH, Shintaku IP, Taylor EJ, Robert L, Chmielowski B, Spasic M, Henry G, Ciobanu V, West AN, Carmona M, Kivork C, Seja E, Cherry G, Gutierrez AJ, Grogan TR, Mateus C, Tomasic G, Glaspy JA, Emerson RO, Robins H, Pierce RH, Elashoff DA, Robert C, Ribas A. PD-1 blockade induces responses by inhibiting adaptive immune resistance. Nature 2014; 515(7528): 568-571

26. Marianne J. Ratcliffe AS, Midha A, Barker C, Scorer P, Walker J. A comparative study of PD-L1 diagnostic assays and the classification of patients as PD-L1 positive and PD-L1 negative. [abstract]. In: Proceedings of the 107th Annual Meeting of the American Association for Cancer Research; 2016 Apr 16-20; New Orleans, LA. Philadelphia (PA): AACR. Cancer Res 2016; 76 (14 Suppl): Abstract nr LB-094

27. Le DT, Uram JN, Wang H, Bartlett BR, Kemberling H, Eyring AD, Skora AD, Luber BS, Azad NS, Laheru D, Biedrzycki B, Donehower RC, Zaheer A, Fisher GA, Crocenzi TS, Lee JJ, Duffy SM, Goldberg RM, de la Chapelle A, Koshiji M, Bhaijee F, Huebner T, Hruban RH, Wood LD, Cuka N, Pardoll DM, Papadopoulos N, Kinzler KW, Zhou S, Cornish TC, Taube JM, Anders RA, Eshleman JR, Vogelstein B, Diaz LA Jr. PD-1 blockade in tumors with mismatch-repair deficiency. N Engl J Med 2015; 372 (26): 2509-2520

28. Rizvi NA, Hellmann MD, Snyder A, Kvistborg P, Makarov V,
Havel JJ, Lee W, Yuan J, Wong P, Ho TS, Miller ML, Rekhtman N, Moreira AL, Ibrahim F, Bruggeman C, Gasmi B, Zappasodi R, Maeda Y, Sander C, Garon EB, Merghoub T, Wolchok JD, Schumacher TN, Chan TA. Mutational landscape determines sensitivity to PD-1 blockade in non-small cell lung cancer. Science 2015; 348(6230): 124-128

29. Lawrence MS, Stojanov P, Polak P, Kryukov GV, Cibulskis K, Sivachenko A, Carter SL, Stewart C, Mermel CH, Roberts SA, Kiezun A, Hammerman PS, McKenna A, Drier Y, Zou L, Ramos AH, Pugh TJ, Stransky N, Helman E, Kim J, Sougnez C, Ambrogio L, Nickerson E, Shefler E, Cortés ML, Auclair D, Saksena G, Voet D, Noble M, DiCara D, Lin P, Lichtenstein L, Heiman DI, Fennell T, Imielinski M, Hernandez B, Hodis E, Baca S, Dulak AM, Lohr J, Landau DA, Wu CJ, Melendez-Zajgla J, Hidalgo-Miranda A, Koren A, McCarroll SA, Mora J, Crompton B, Onofrio R, Parkin M, Winckler W, Ardlie K, Gabriel SB, Roberts CWM, Biegel JA, Stegmaier K, Bass AJ, Garraway LA, Meyerson M, Golub TR, Gordenin DA, Sunyaev S, Lander ES, Getz G. Mutational heterogeneity in cancer and the search for new cancer-associated genes. Nature 2013; 499(7457): 214-218

30. Snyder A, Makarov V, Merghoub T, Yuan J, Zaretsky JM, Desrichard A, Walsh LA, Postow MA, Wong P, Ho TS, Hollmann TJ, Bruggeman C, Kannan K, Li Y, Elipenahli C, Liu C, Harbison CT, Wang L, Ribas A, Wolchok JD, Chan TA. Genetic basis for clinical response to CTLA-4 blockade in melanoma. N Engl J Med 2014; 371(23): 2189-2199

31. Rosenberg JE, Hoffman-Censits J, Powles T, van der Heijden MS, Balar AV, Necchi A, Dawson N, O’Donnell PH, Balmanoukian A, Loriot Y, Srinivas S, Retz MM, Grivas P, Joseph RW, Galsky MD, Fleming MT, Petrylak DP, Perez-Gracia JL, Burris HA, Castellano D, Canil C, Bellmunt J, Bajorin D, Nickles D, Bourgon R, Frampton GM, Cui N, Mariathasan S, Abidoye O, Fine GD, Dreicer R. Atezolizumab in patients with locally advanced and metastatic urothelial carcinoma who have progressed following treatment with platinum-based chemotherapy: a single-arm, multicentre, phase 2 trial. Lancet 2016; 387(10031): 1909-1920

32. Spencer KR, Wang J, Silk AW, Ganesan S, Kaufman HL, Mehnert JM. Biomarkers for immunotherapy: current developments and challenges. Am Soc Clin Oncol Educ Book 2016; 35(36): e493e503

33. McGranahan N, Furness AJ, Rosenthal R, Ramskov S, Lyngaa R, Saini SK, Jamal-Hanjani M, Wilson GA, Birkbak NJ, Hiley CT, Watkins TB, Shafi S, Murugaesu N, Mitter R, Akarca AU, Linares J, Marafioti T, Henry JY, Van Allen EM, Miao D, Schilling B, Schadendorf D, Garraway LA, Makarov V, Rizvi NA, Snyder A, Hellmann MD, Merghoub T, Wolchok JD, Shukla SA, Wu CJ, Peggs KS, Chan TA, Hadrup SR, Quezada SA, Swanton C. Clonal neoantigens elicit $\mathrm{T}$ cell immunoreactivity and sensitivity to immune checkpoint blockade. Science 2016; 351(6280): 14631469

34. Birnbaum ME, Mendoza JL, Sethi DK, Dong S, Glanville J, Dobbins J, Ozkan E, Davis MM, Wucherpfennig KW, Garcia KC. Deconstructing the peptide-MHC specificity of $\mathrm{T}$ cell recognition. Cell 2014; 157(5): 1073-1087

35. Van Allen EM, Miao D, Schilling B, Shukla SA, Blank C, Zimmer L, Sucker A, Hillen U, Foppen MHG, Goldinger SM, Utikal J, Hassel JC, Weide B, Kaehler KC, Loquai C, Mohr P, Gutzmer R, Dummer R, Gabriel S, Wu CJ, Schadendorf D, Garraway LA. 
Genomic correlates of response to CTLA-4 blockade in metastatic melanoma. Science 2015; 350(6257): 207-211

36. Drake JW, Charlesworth B, Charlesworth D, Crow JF. Rates of spontaneous mutation. Genetics 1998; 148(4): 1667-1686

37. Kunkel TA, Bebenek K. DNA replication fidelity. Annu Rev Biochem 2000; 69(1): 497-529

38. Preston BD, Albertson TM, Herr AJ. DNA replication fidelity and cancer. Semin Cancer Biol 2010; 20(5): 281-293

39. Le DT, Durham JN, Smith KN, Wang H, Bartlett BR, Aulakh LK, Lu S, Kemberling H, Wilt C, Luber BS, Wong F, Azad NS, Rucki AA, Laheru D, Donehower R, Zaheer A, Fisher GA, Crocenzi TS, Lee JJ, Greten TF, Duffy AG, Ciombor KK, Eyring AD, Lam BH, Joe A, Kang SP, Holdhoff M, Danilova L, Cope L, Meyer C, Zhou S, Goldberg RM, Armstrong DK, Bever KM, Fader AN, Taube J, Housseau F, Spetzler D, Xiao N, Pardoll DM, Papadopoulos N, Kinzler KW, Eshleman JR, Vogelstein B, Anders RA, Diaz LA Jr. Mismatch repair deficiency predicts response of solid tumors to PD1 blockade. Science 2017; 357(6349): 409-413

40. Hugo W, Zaretsky JM, Sun L, Song C, Moreno BH, Hu-Lieskovan S, Berent-Maoz B, Pang J, Chmielowski B, Cherry G, Seja E, Lomeli S, Kong X, Kelley MC, Sosman JA, Johnson DB, Ribas A, Lo RS. Genomic and transcriptomic features of response to anti-PD1 therapy in metastatic melanoma. Cell 2016; 165(1): 35-44

41. Gajewski TF, Schreiber H, Fu YX. Innate and adaptive immune cells in the tumor microenvironment. Nat Immunol 2013; 14(10): 1014-1022

42. Galon J, Costes A, Sanchez-Cabo F, Kirilovsky A, Mlecnik B, Lagorce-Pagès C, Tosolini $\mathrm{M}$, Camus $\mathrm{M}$, Berger A, Wind $\mathrm{P}$, Zinzindohoué F, Bruneval P, Cugnenc PH, Trajanoski Z, Fridman WH, Pagès F. Type, density, and location of immune cells within human colorectal tumors predict clinical outcome. Science 2006; 313(5795): 1960-1964

43. Jochems C, Schlom J. Tumor-infiltrating immune cells and prognosis: the potential link between conventional cancer therapy and immunity. Exp Biol Med (Maywood) 2011; 236(5): 567-579

44. Mlecnik B, Tosolini M, Kirilovsky A, Berger A, Bindea G, Meatchi T, Bruneval P, Trajanoski Z, Fridman WH, Pagès F, Galon J. Histopathologic-based prognostic factors of colorectal cancers are associated with the state of the local immune reaction. J Clin Oncol 2011; 29(6): 610-618

45. Pagès F, Berger A, Camus M, Sanchez-Cabo F, Costes A, Molidor R, Mlecnik B, Kirilovsky A, Nilsson M, Damotte D, Meatchi T, Bruneval P, Cugnenc PH, Trajanoski Z, Fridman WH, Galon J. Effector memory $T$ cells, early metastasis, and survival in colorectal cancer. N Engl J Med 2005; 353(25): 2654-2666

46. Kluger HM, Zito CR, Barr ML, Kluger HM, Zito CR, Barr ML, Baine MK, Chiang VLS, Sznol M, Rimm DL, Chen LP, Jilaveanu LB. Characterization of PD-L1 expression and associated T-cell infiltrates in metastatic melanoma samples from variable anatomic sites. Clin Cancer Res 2015; 21(13): 3052-3060

47. Zhang L, Conejo-Garcia JR, Katsaros D, Gimotty PA, Massobrio M, Regnani G, Makrigiannakis A, Gray H, Schlienger K, Liebman MN, Rubin SC, Coukos G. Intratumoral T cells, recurrence, and survival in epithelial ovarian cancer. N Engl J Med 2003; 348(3): 203-213

48. Ladanyi A, Somlai B, Gilde K, Fejos Z, Gaudi I, Timar J. T-cell activation marker expression on tumor-infiltrating lymphocytes as prognostic factor in cutaneous malignant melanoma. Clin Cancer
Res 2004; 10(2): 521-530

49. Hiraoka K, Miyamoto M, Cho Y, Suzuoki M, Oshikiri T, Nakakubo Y, Itoh T, Ohbuchi T, Kondo S, Katoh H. Concurrent infiltration by $\mathrm{CD} 8^{+} \mathrm{T}$ cells and $\mathrm{CD} 4^{+} \mathrm{T}$ cells is a favourable prognostic factor in non-small-cell lung carcinoma. Br J Cancer 2006; 94(2): 275-280

50. Calabrò L, Maio M. Immune checkpoint blockade in malignant mesothelioma. Semin Oncol 2015; 42(3): 418-422

51. Chen H, Liakou CI, Kamat A, Pettaway C, Ward JF, Tang DN, Sun J, Jungbluth AA, Troncoso P, Logothetis C, Sharma P. Anti-CTLA4 therapy results in higher $\mathrm{CD} 4{ }^{+} \mathrm{ICOS}^{\text {hi }} \mathrm{T}$ cell frequency and IFN- $\gamma$ levels in both nonmalignant and malignant prostate tissues. Proc Natl Acad Sci USA 2009; 106(8): 2729-2734

52. Liakou CI, Kamat A, Tang DN, Chen H, Sun J, Troncoso P, Logothetis C, Sharma P. CTLA-4 blockade increases IFN $\gamma$ producing $\mathrm{CD} 4{ }^{+} \mathrm{ICOS}^{\text {hi }}$ cells to shift the ratio of effector to regulatory T cells in cancer patients. Proc Natl Acad Sci USA 2008; 105(39): 14987-14992

53. Vonderheide RH, LoRusso PM, Khalil M, Gartner EM, Khaira D, Soulieres D, Dorazio P, Trosko JA, Rüter J, Mariani GL, Usari T, Domchek SM. Tremelimumab in combination with exemestane in patients with advanced breast cancer and treatment-associated modulation of inducible costimulator expression on patient $\mathrm{T}$ cells. Clin Cancer Res 2010; 16(13): 3485-3494

54. Ng Tang D, Shen Y, Sun J, Wen S, Wolchok JD, Yuan J, Allison JP, Sharma P. Increased frequency of ICOS $+\mathrm{CD} 4 \mathrm{~T}$ cells as a pharmacodynamic biomarker for anti-CTLA-4 therapy. Cancer Immunol Res 2013; 1(4): 229-234

55. Huh JW, Lee JH, Kim HR. Prognostic significance of tumorinfiltrating lymphocytes for patients with colorectal cancer. Arch Surg 2012; 147(4): 366-372

56. Thomas NE, Busam KJ, From L, Kricker A, Armstrong BK, AntonCulver H, Gruber SB, Gallagher RP, Zanetti R, Rosso S, Dwyer T, Venn A, Kanetsky PA, Groben PA, Hao H, Orlow I, Reiner AS, Luo L, Paine S, Ollila DW, Wilcox H, Begg CB, Berwick M. Tumorinfiltrating lymphocyte grade in primary melanomas is independently associated with melanoma-specific survival in the population-based genes, environment and melanoma study. J Clin Oncol 2013; 31(33): 4252-4259

57. Zeng DQ, Yu YF, Ou QY, Li XY, Zhong RZ, Xie CM, Hu QG. Prognostic and predictive value of tumor-infiltrating lymphocytes for clinical therapeutic research in patients with non-small cell lung cancer. Oncotarget 2016; 7(12): 13765-13781

58. Messina JL, Fenstermacher DA, Eschrich S, Qu X, Berglund AE, Lloyd MC, Schell MJ, Sondak VK, Weber JS, Mulé JJ. 12Chemokine gene signature identifies lymph node-like structures in melanoma: potential for patient selection for immunotherapy? Sci Rep 2012; 2(1): 765

59. Tokito T, Azuma K, Kawahara A, Ishii H, Yamada K, Matsuo N, Kinoshita T, Mizukami N, Ono H, Kage M, Hoshino T. Predictive relevance of PD-L1 expression combined with $\mathrm{CD}^{+}$TIL density in stage III non-small cell lung cancer patients receiving concurrent chemoradiotherapy. Eur J Cancer 2016; 55: 7-14

60. Gibney GT, Weiner LM, Atkins MB. Predictive biomarkers for checkpoint inhibitor-based immunotherapy. Lancet Oncol 2016; 17 (12): e542-e551

61. Hamid O, Schmidt H, Nissan A, Ridolfi L, Aamdal S, Hansson J, Guida M, Hyams DM, Gómez H, Bastholt L, Chasalow SD, Berman 
D. A prospective phase II trial exploring the association between tumor microenvironment biomarkers and clinical activity of ipilimumab in advanced melanoma. J Transl Med 2011; 9(1): 204

62. Galon J, Mlecnik B, Bindea G, Angell HK, Berger A, Lagorce C, Lugli A, Zlobec I, Hartmann A, Bifulco C, Nagtegaal ID, Palmqvist R, Masucci GV, Botti G, Tatangelo F, Delrio P, Maio M, Laghi L, Grizzi F, Asslaber M, D’Arrigo C, Vidal-Vanaclocha F, Zavadova E, Chouchane L, Ohashi PS, Hafezi-Bakhtiari S, Wouters BG, Roehrl M, Nguyen L, Kawakami Y, Hazama S, Okuno K, Ogino S, Gibbs P, Waring P, Sato N, Torigoe T, Itoh K, Patel PS, Shukla SN, Wang Y, Kopetz S, Sinicrope FA, Scripcariu V, Ascierto PA, Marincola FM, Fox BA, Pagès F. Towards the introduction of the 'Immunoscore' in the classification of malignant tumours. J Pathol 2014; 232 (2): 199-209

63. Tsuchiya J, Maekawa T. Cytokinetic studies on hematopoietic cells of the bone marrow. Nihon Ketsueki Gakkai Zasshi 1973; 36(5): 641-660

64. Galon J, Fox BA, Bifulco CB, Masucci G, Rau T, Botti G, Marincola FM, Ciliberto G, Pages F, Ascierto PA, Capone M. Immunoscore and immunoprofiling in cancer: an update from the melanoma and immunotherapy bridge 2015. J Transl Med 2016; 14 (1): 273

65. Pagès F, Kirilovsky A, Mlecnik B, Asslaber M, Tosolini M, Bindea G, Lagorce C, Wind P, Marliot F, Bruneval P, Zatloukal K, Trajanoski Z, Berger A, Fridman WH, Galon J. In situ cytotoxic and memory $\mathrm{T}$ cells predict outcome in patients with early-stage colorectal cancer. J Clin Oncol 2009; 27(35): 5944-5951

66. Nishino M, Ramaiya NH, Hatabu H, Hodi FS. Monitoring immunecheckpoint blockade: response evaluation and biomarker development. Nat Rev Clin Oncol 2017; 14(11): 655-668

67. Ascierto PA, Capone M, Urba WJ, Bifulco CB, Botti G, Lugli A, Marincola FM, Ciliberto G, Galon J, Fox BA. The additional facet of immunoscore: immunoprofiling as a possible predictive tool for cancer treatment. J Transl Med 2013; 11(1): 54

68. Paulsen EE, Kilvaer TK, KhanehkenariMR, Al-SaadS, Hald SM, AndersenS, RichardsenE, NessN, Busund LT, Bremnes RM, DonnemT. Assessing PDL-1 and PD-1 in non-small cell lung cancer: a novel immunoscore approach. Clin Lung Cancer 2017; 18(2): 220333.e8

69. Yuan J, Zhou J, Dong Z, Tandon S, Kuk D, Panageas KS, Wong P, Wu X, Naidoo J, Page DB, Wolchok JD, Hodi FS. Pretreatment serum VEGF is associated with clinical response and overall survival in advanced melanoma patients treated with ipilimumab. Cancer Immunol Res 2014; 2(2): 127-132

70. Kelderman S, Heemskerk B, van Tinteren H, van den Brom RR, Hospers GA, van den Eertwegh AJ, Kapiteijn EW, de Groot JW, Soetekouw P, Jansen RL, Fiets E, Furness AJ, Renn A, Krzystanek M, Szallasi Z, Lorigan P, Gore ME, Schumacher TN, Haanen JB, Larkin JM, Blank CU. Lactate dehydrogenase as a selection criterion for ipilimumab treatment in metastatic melanoma. Cancer Immunol Immunother 2014; 63(5): 449-458

71. Simeone E, Gentilcore G, Giannarelli D, Grimaldi AM, Caracò C, Curvietto M, Esposito A, Paone M, Palla M, Cavalcanti E, Sandomenico F, Petrillo A, Botti G, Fulciniti F, Palmieri G, Queirolo P, Marchetti P, Ferraresi V, Rinaldi G, Pistillo MP, Ciliberto G, Mozzillo N, Ascierto PA. Immunological and biological changes during ipilimumab treatment and their potential correlation with clinical response and survival in patients with advanced melanoma. Cancer Immunol Immunother 2014; 63(7): 675-683

72. Hannani D, Vétizou M, Enot D, Rusakiewicz S, Chaput N, Klatzmann D, Desbois M, Jacquelot N, Vimond N, Chouaib S, Mateus C, Allison JP, Ribas A, Wolchok JD, Yuan J, Wong P, Postow M, Mackiewicz A, Mackiewicz J, Schadendorff D, Jaeger D, Zörnig I, Hassel J, Korman AJ, Bahjat K, Maio M, Calabro L, Teng MW, Smyth MJ, Eggermont A, Robert C, Kroemer G, Zitvogel L. Anticancer immunotherapy by CTLA-4 blockade: obligatory contribution of IL-2 receptors and negative prognostic impact of soluble CD25. Cell Res 2015; 25(2): 208-224

73. Delyon J, Mateus C, Lefeuvre D, Lanoy E, Zitvogel L, Chaput N, Roy S, Eggermont AM, Routier E, Robert C. Experience in daily practice with ipilimumab for the treatment of patients with metastatic melanoma: an early increase in lymphocyte and eosinophil counts is associated with improved survival. Ann Oncol 2013; 24(6): 1697-1703

74. Martens A, Wistuba-Hamprecht K, Geukes Foppen M, YuanJ, Postow MA, Wong P, Romano E, Khammari A, Dreno B, Capone M, Ascierto PA, Di Giacomo AM, Maio M, Schilling B, Sucker A, Schadendorf D, Hassel JC, Eigentler TK, Martus P, Wolchok JD, Blank C, Pawelec G, Garbe C, Weide B. Baseline peripheral blood biomarkers associated with clinical outcome of advanced melanoma patients treated with ipilimumab. Clin Cancer Res 2016; 22(12): 2908-2918

75. Schmidt H, Suciu S, Punt CJ, Gore M, Kruit W, Patel P, Lienard D, von der Maase H, Eggermont AM, Keilholz U; American Joint Committee on Cancer Stage IV Melanoma; EORTC 18951. Pretreatment levels of peripheral neutrophils and leukocytes as independent predictors of overall survival in patients with American Joint Committee on Cancer Stage IV Melanoma: results of the EORTC 18951 Biochemotherapy Trial. J Clin Oncol 2007; 25(12): 1562-1569

76. Meyer C, Cagnon L, Costa-Nunes CM, Baumgaertner P, Montandon N, Leyvraz L, Michielin O, Romano E, Speiser DE. Frequencies of circulating MDSC correlate with clinical outcome of melanoma patients treated with ipilimumab. Cancer Immunol Immunother 2014; 63(3): 247-257

77. Yuan J, Adamow M, Ginsberg BA, Rasalan TS, Ritter E, Gallardo HF, Xu Y, Pogoriler E, Terzulli SL, Kuk D, Panageas KS, Ritter G, Sznol M, Halaban R, Jungbluth AA, Allison JP, Old LJ, Wolchok JD, Gnjatic S. Integrated NY-ESO-1 antibody and $\mathrm{CD}^{+}$T-cell responses correlate with clinical benefit in advanced melanoma patients treated with ipilimumab. Proc Natl Acad Sci USA 2011; 108(40): 16723-16728

78. Mandal R, Chan TA. Personalized oncology meets immunology: the path toward precision immunotherapy. Cancer Discov 2016; 6(7): 703-713

79. Sivan A, Corrales L, Hubert N, Williams JB, Aquino-Michaels K, Earley ZM, Benyamin FW, Lei YM, Jabri B, Alegre ML, Chang EB, Gajewski TF. Commensal Bifidobacterium promotes antitumor immunity and facilitates anti-PD-L1 efficacy. Science 2015; 350 (6264): 1084-1089

80. Vétizou M, Pitt JM, Daillère R, Lepage P, Waldschmitt N, Flament C, Rusakiewicz S, Routy B, Roberti MP, Duong CP, Poirier-Colame V, Roux A, Becharef S, Formenti S, Golden E, Cording S, Eberl G, Schlitzer A, Ginhoux F, Mani S, Yamazaki T, Jacquelot N, Enot DP, Bérard M, Nigou J, Opolon P, Eggermont A, Woerther PL, Chachaty E, Chaput N, Robert C, Mateus C, Kroemer G, Raoult D, 
Boneca IG, Carbonnel F, Chamaillard M, Zitvogel L. Anticancer immunotherapy by CTLA-4 blockade relies on the gut microbiota. Science 2015; 350(6264): 1079-1084

81. Routy B, Le Chatelier E, Derosa L, Duong CPM, Alou MT, Daillère R, Fluckiger A, Messaoudene M, Rauber C, Roberti MP, Fidelle M, Flament C, Poirier-Colame V, Opolon P, Klein C, Iribarren K, Mondragón L, Jacquelot N, Qu B, Ferrere G, Clémenson C, Mezquita L, Masip JR, Naltet C, Brosseau S, Kaderbhai C, Richard C, Rizvi H, Levenez F, Galleron N, Quinquis B, Pons N, Ryffel B, Minard-Colin V, Gonin P, Soria JC, Deutsch E, Loriot Y, Ghiringhelli F, Zalcman G, Goldwasser F, Escudier B, Hellmann MD, Eggermont A, Raoult D, Albiges L, Kroemer G, Zitvogel L. Gut microbiome influences efficacy of PD-1-based immunotherapy against epithelial tumors. Science 2018; 359(6371): 91-97

82. Gopalakrishnan V, Spencer CN, Nezi L, Reuben A, Andrews MC, Karpinets TV, Prieto PA, Vicente D, Hoffman K, Wei SC, Cogdill AP, Zhao L, Hudgens CW, Hutchinson DS, Manzo T, Petaccia de
Macedo M, Cotechini T, Kumar T, Chen WS, Reddy SM, Szczepaniak Sloane R, Galloway-Pena J, Jiang H, Chen PL, Shpall EJ, Rezvani K, Alousi AM, Chemaly RF, Shelburne S, Vence LM, Okhuysen PC, Jensen VB, Swennes AG, McAllister F, Marcelo Riquelme Sanchez E, Zhang Y, Le Chatelier E, Zitvogel L, Pons N, Austin-Breneman JL, Haydu LE, Burton EM, Gardner JM, Sirmans E, Hu J, Lazar AJ, Tsujikawa T, Diab A, Tawbi H, Glitza IC, Hwu WJ, Patel SP, Woodman SE, Amaria RN, Davies MA, Gershenwald JE, Hwu P, Lee JE, Zhang J, Coussens LM, Cooper ZA, Futreal PA, Daniel CR, Ajami NJ, Petrosino JF, Tetzlaff MT, Sharma P, Allison JP, Jenq RR, Wargo JA. Gut microbiome modulates response to anti-PD-1 immunotherapy in melanoma patients. Science 2018; 359 (6371): 97-103

83. Matson V, Fessler J, Bao R, Chongsuwat T, Zha Y, Alegre ML, Luke JJ, Gajewski TF. The commensal microbiome is associated with anti-PD-1 efficacy in metastatic melanoma patients. Science 2018; 359(6371): 104-108 